\author{
NBER WORKING PAPER SERIES \\ ON \\ HISTORICAL FACTORS IN LONG-RUN GROWTH \\ LONG TERM CHANGES IN U.S. AGRICULTURAL \\ OUTPUT PER WORKER, 1800 TO 1900
}

Thomas Weiss

Working Paper No. 23

NATIONAL BUREAU OF ECONOMIC RESEARCH

1050 Massachusetts Avenue

Cambridge, MA 02138

February 1991

This paper is part of NBER's research program in Development of the American Economy. Any opinions expressed are those of the author and not those of the National Bureau of Economic Research. 
NBER Working Paper \#23

February 1991

\section{LONG TERM CHANGES IN U.S. AGRICULTURAL \\ OUTPUT PER WORKER, 1800 TO 1900}

\section{$\underline{\text { ABSTRACT }}$}

The nineteenth century was a period of expansion and transformation of American agriculture. While much is known about the process, the exact pace and timing of agricultural productivity change is still unresolved.

The traditional view is one of continued progress in which output and productivity increased steadily, accelerating over the period. The Civil war is seen as a convenient turning point, and perhaps an episode of greater consequence. More recent work has raised doubts about this picture of steady and accelerating success. The extant statistics on farm output and its labor force indicate that the period before the civil war had the superior record and experienced particularly rapid productivity growth between 1820 and 1840 .

This paper presents new estimates of agricultural output per worker, based on revised statistics of the farm labor force and farm gross product. These new figures present a picture of agricultural progress more like the traditional view. Farm productivity grew noticeably faster after the Civil war than before, and important changes appear to have occurred during the Civil War decade.

Thomas Weiss

Department of Economics Summerfield Hall University of Kansas Lawrence, KS 66045 
The nineteenth century was a long transitional period for American agriculture, during which the industry shifted from nascent commercialization serving local and regional markets to a large-scale, science-based production for interregional and international markets. 2 The sector's performance during this transition was good, but not outstanding. Given the rapid growth of U.S. population, much additional output was needed just to maintain standards of living, and farmers were up to the task. Agriculture produced a swelling output with little or no increase in prices, and accomplished it with a decline in the relative importance of its labor force. ${ }^{3}$ The exact pace and timing of the agricultural productivity change underlying that performance, however, is still unknown. ${ }^{4}$ A more accurate picture of that productivity change is needed to better understand how economic growth came about during the century, especially before 1840, and to unravel broader issues relating to farm and rural society, such as the decline of family farming.

I

In what can be called the traditional view the century saw continued progress in which output and productivity increased steadily, quite likely accelerating over the period. Early on farmers exploited the limited markets that had been developed during the colonial period, and began searching for better markets and production techniques. 5 The search for improved methods, whether mechanical, biological, or chemical, met with sporadic and limited success initially, but eventually proved fruitful. The unresolved matter is whether all these experiments 
came to fruition, in the sense of generating a sharp acceleration in productivity, and if so when.

one strand of this traditional line of thought emphasizes the steadiness of advance, deemphasizing the idea of an agricultural revolution. Earle Ross and Robert Tontz concluded that since writers have placed the revolution anywhere from the half-century before the Civil war to the two decades between the World Wars, 'our "revolution," if so it can be called, is a continuing one that, thus far, has developed through several fairly distinct stages.' 6 They felt the developments should be more appropriately labeled an evolution. 7 william Parker's view seems much like this. Agricultural development was shaped by three forces - the westward movement, market growth and technical change - but the opportunities arising out of each were numerous and subject to spurts so that 'their combined result, from the perspective of two centuries, is one of continuity, of gradual, steady expansion and improvement. 18

other historians have identified various times at which an agricultural revolution took place, even if they have not always been clear what was meant by it. The most common view is to mark the civil War as a turning point '... in the judgment of most writers on the subject, the influences that revolutionized the American countryside were generated in that most available if not always exact period of division in American history, the Civil War.'9 This view is very much alive as evidenced by Hurt's recent affirmation 'American agriculture underwent revolutionary change during the civil war.'10 For many the war was only the 
beginning, and 'The first American Agricultural Revolution' was extended over the period 1861 to 1914.11 In the half century after the Civil War 'Basic applications of the principles discovered in the biological and physical sciences during the first half of the nineteenth century now brought a trend toward what the English have termed "high farming" as contrasted with the extensive methods of cultivation and husbandry previously used. 12

Some historians have placed the productivity acceleration a bit earlier. Bogart puts the shift just prior to the civil War 'As late as 1830 practically every part of the work of the farm,....was done by hand... By 1860 the farming industry had been revolutionized in respect of practically every one of these processes by the invention and introduction of farm machinery ...No period of equal length in the history of agriculture has witnessed such revolutionary changes.'13 Lewis Gray, one of the most noted agricultural historians, claimed 'The first four decades of the nineteenth century were characterized by important beginnings in agricultural progress, rather than by striking or revolutionary accomplishments. It was a period of preparation both in the technical and in the business sides of farming preparation for subsequent progress and expansion.'14 Willard Cochrane agreed '... all these machines - plows, harrows, planters, cultivators, reapers, and threshers - ..tended to be developed in the 1820 s and 1830s, to be adopted commercially on a limited basis in the 1840s, and to come into common usage in the 1850s..'15 Danhof saw the period 1820 to 1850 as a time of 
experimentation which 'inaugurated the modern age of agricultural technology. By 1860 the foundations for a mechanized farming economy had been securely laid.'16 Even Cooper, Barton, and Brodell who calculated substantial productivity advances in corn, cotton, and especially wheat production before 1840, remarked that 'the year 1840 marks the beginning of worth-while results by inventors and experimenters who had been making persistent trials and studies throughout 50 years.'17

While the traditional views disagreed about the specific timing and degree of acceleration in agricultural productivity advance, there seems widespread agreement that it could not have occurred much before 1840.18 More recent work has raised doubts about this timing and the picture of steady and accelerating success. The extant statistics on farm output and the farm labor force indicate that there was virtually no difference in the growth rate of output per worker before and after the Civil war, and that output per worker increased faster before 1840 than it did afterwards. As can be seen in Table 1 labor productivity increased in any of the major antebellum subperiods at about the same rate as it did over the entire century. Within the antebellum period the most rapid years of advance occurred before 1840 rather than after, and more specifically, the increases in the years 1820 to 1840 were the most rapid of the century. 19

Yet more recent work has challenged this revisionist view. Gallman has argued that the extant figures for the antebellum farm labor force were a likely source of bias in the output per worker series. In particular he questioned the time pattern of 
farm productivity advance over the nineteenth century implied by the Lebergott labor force estimates because they suggested unlikely changes in the number of hours worked per farm worker, and implied that farm productivity had increased more rapidy in the first half of the century than in the latter half. 20 Gallman was not entirely correct in identifying the years in which the labor force figures might have been flawed, or the exact extent of the error, but his questions about the accuracy of the farm workforce series were well placed.

This article sets forth new estimates of U.S. farm labor productivity covering the nineteenth century that present a picture of growth much like the traditional view (See Table 1). In particular, farm productivity in the antebellum years grew more slowly than depicted in the revisionist view and showed far greater acceleration after the civil war. The exact extent of the post-1860 period's superior performance rests in part on the definition of farm output, being more pronounced in a narrow measure which excludes the value of farm improvements and home manufacturing. For the entire century the choice of measure also makes a difference. Using the narrowly defined output the performance with either labor force series was nearly identical, but with the more inclusive measure the new productivity series shows a slower rate of advance.

The differences between the extant statistical series (hereafter called the original) and my revised one reflect the combined effect of adjustments to the output and labor force series. The original farm productivity series is based on the 
Table 1

Comparison of Agricultural output per Worker

Average Annualized Rates of Change

\begin{tabular}{lrccc} 
& $\begin{array}{c}\text { Narrow Definition } \\
\text { of output } \\
\text { original Revised }\end{array}$ & \multicolumn{2}{c}{$\begin{array}{c}\text { Broad Definition } \\
\text { of Output } \\
\text { Original Revised }\end{array}$} \\
1800 to 1840 & .79 & .29 & .71 & .21 \\
1840 to 1900 & .67 & .97 & .58 & .67 \\
1800 to 1850 & .66 & .24 & .60 & .20 \\
1850 to 1900 & .78 & 1.15 & .66 & .78 \\
1800 to 1860 & .70 & .38 & .61 & .30 \\
1860 to 1900 & .75 & 1.17 & .66 & .77 \\
1800 to 1900 & .72 & .70 & .63 & .49
\end{tabular}

Notes: The narrow definition of output excludes the value of farm improvements and home manufacturing, the broad definition includes them. Both series are in constant prices of 1840 .

The original figures are based on the output per worker series obtained by dividing the original Towne and Rasmussen farm gross product figures by Lebergott's farm labor force.

The revised figures are based on the output per worker series obtained by dividing a revised farm gross product series by the Weiss farm labor force series. These series are described below.

Sources: Tables $4 \mathrm{~A}$ and $4 \mathrm{~B}$ below. 
output estimates of Marvin Towne and Wayne Rasmussen and the labor force data of stanley Lebergott. 21 The revised figures were calculated using a corrected version of the Towne-Rasmussen output series and my new labor force estimates. As will be seen, the revisions to the farm labor force estimates have a greater effect on the productivity differences, but the output series has bearing as well.

The Towne and Rasmussen farm gross product figures have been available for 30 years, and have been widely used.22 The series combines figures of differing reliability, and which were estimated in various ways. Of some importance is the fact that for the period before 1840 a large share of output was estimated by assuming a constant amount per capita. 23

The original figures, revalued in 1840 prices, are presented in Table 2 in per capita terms, and organized by the method of estimation. There was very little increase in per capita output over the course of the century, only $\$ 7$ in the narrow measure, $\$ 4$ in the broad one. The estimation methods precluded much of an increase before 1840 because the bulk of the sector's output was composed of products whose values were estimated on a constant per capita basis. These population based figures made up over three-fourths of the broad measure and over 80 percent of the narrow. Even after 1840, however, there was very little increase, about the same as had occurred before.

My revised figures do not change this broad pattern very much. One difference is due to the changes I made to three 
Table 2

Towne and Rasmussen's Estimates of Farm Gross Product per Capita

(1840 prices)

$\begin{array}{lrrrrr}\text { Year } & \begin{array}{c}\text { Output of Crop and } \\ \text { Livestock } \\ \text { Products } \\ \text { Population } \\ \text { Based }\end{array} & \begin{array}{c}\text { Other } \\ \text { Items }\end{array} & \begin{array}{c}\text { Farm Gross } \\ \text { Narrow } \\ \text { Definition }\end{array} & \begin{array}{c}\text { Product } \\ \text { Broad } \\ \text { Definition }\end{array} \\ 1800 & \$ 1.89 & \$ 34.32 & \$ 2.24 & \$ 38.45 & \$ 42.45 \\ 1810 & 2.45 & 33.56 & 2.06 & 38.06 & 41.90 \\ 1820 & 3.00 & 33.23 & 1.81 & 38.04 & 41.71 \\ 1830 & 4.34 & 33.19 & 1.88 & 39.41 & 42.78 \\ 1840 & 5.92 & 34.99 & 1.23 & 42.18 & 45.05 \\ 1850 & 6.68 & 31.57 & 1.02 & 39.27 & 42.19 \\ 1860 & 8.54 & 32.39 & -75 & 41.67 & 43.75 \\ 1870 & 7.51 & 32.07 & -.11 & 39.46 & 41.15 \\ 1880 & 9.38 & 38.06 & -.96 & 46.48 & 47.91 \\ 1890 & 10.32 & 36.61 & -1.48 & 45.44 & 46.34 \\ 1900 & 10.33 & 37.53 & -2.20 & 45.67 & 46.30\end{array}$

Sources: Towne and Rasmussen, 'Farm Gross Product,' revalued in. 1840 prices.

Notes: The population-based figures are for those crops and livestock products which Towne and Rasmussen specified as having been estimated by assuming a constant per capita value from 1800 through 1840. The population-based estimates of wheat, corn, and tobacco output were supplemented by the value of exports.

The figure for 'other items' is the net amount of the value of inventory change plus the gross rental value of farm dwellings minus the value of intermediate products used up in production. Most of the variation over time results from the rise in the value of intermediate products. The per capita value of inventory changes declined from $\$ 1.04$ in 1800 to $\$ .61$ in 1900 , that for shelter rose slightly from $\$ 2.45$ to $\$ 3.01$, and the intermediate products rose from $\$ 1.24$ to $\$ 5.82$.

The sum of the first three columns equals the narrowly defined measure of farm gross product. The difference between the narrow and broad measures is the inclusion in the latter of the value of farm improvements and home manufacturing; the value of farm improvements declined from $\$ 1.85$ in 1800 to $\$ .58$ in 1900 , that of home manufacturing declined from $\$ 2.06$ to $\$ .06$. 
product series in order to correct for some surprising variations in the per capita values of those products before 1840. On a per capita basis, there was unexpected variation in the output of hogs, cattle and calves, and fruit. Quite striking is the rise in their per capita values in the twenty years before 1840 when they were supposed to have reflected the assumption of constancy in the per capita amount. 24 After 1840 the behavior represents the actual course of events, at least as recorded by the census. This surprising pattern reflects an anomaly in their estimation procedures. For each of these products the 1840 census value was relatively high compared to subsequent years, and Towne and Rasmussen chose not to use that year's figures alone to estimate the values for the earlier years. Instead they used a lower figure - the average of the values for 1840, 1850, and 1860.25 In consequence, they constructed the trend reversal. It is unlikely that 1840 was a peak year for the production of these products, and Towne and Rasmussen presented no arguments for establishing it as a turning point. 26 Moreover, there is no reason for thinking that the years before 1840 had noticeably different livestock output records on a per capita basis. In fact, the anthropometric evidence, that average heights which had been quite stable since 1780 began to decline after 1835 and perhaps as early as 1820, suggests that output per capita, especially hog production, may have declined from 1820 or earlier down to the 20 th century. 27 The 1840 figure seems a better approximation of the level of per capita meat output in the earliex years than is a lower value based on the average of 1840 
and later years, so I used it as the base for extrapolation to 1800.28 The consequence of this correction is quite small, changing output per capita by about $\$ 1.00$.

Larger revisions were made to the broader measure of farm gross product. 29 The biggest change was in the value of home manufacturing, about $\$ 5$ per capita in the antebellum years but much smaller after the civil War. The revisions to the value of farm improvements before the war, increases ranging from $\$ .60$ to 1.20, are about equal in size to the adjustments to the crop and livestock figures.

The effects of the revisions can be usefully seen by comparing the rates of growth of the original and revised output series (Table 3). The impact on the narrowly defined output is confined entirely to the antebellum period, especially the l830s; the century long growth of that series is virtually unchanged. Using the broader definition the revisions alter the rates of growth in the ante- and postbellum periods and over the entire century. In the antebellum years the effect in the broad measure is a very small reduction with the greatest impact occurring in the 1820 to 1840 period. In the postbellum period the revisions lower the growth rate by .35 percent per year, the biggest change showing up in the 1870s. Over the entire century the growth rate is lowered by only .16 percent.

In the original series it made little difference whether one used the narrow or broad measure, the differences in the rates of growth were small; around .l percent with the largest difference (.17 percent) occurring in the 1830s. In the revised series the 
Table 3

Comparison of Rates of Growth of Farm Gross Product Variants

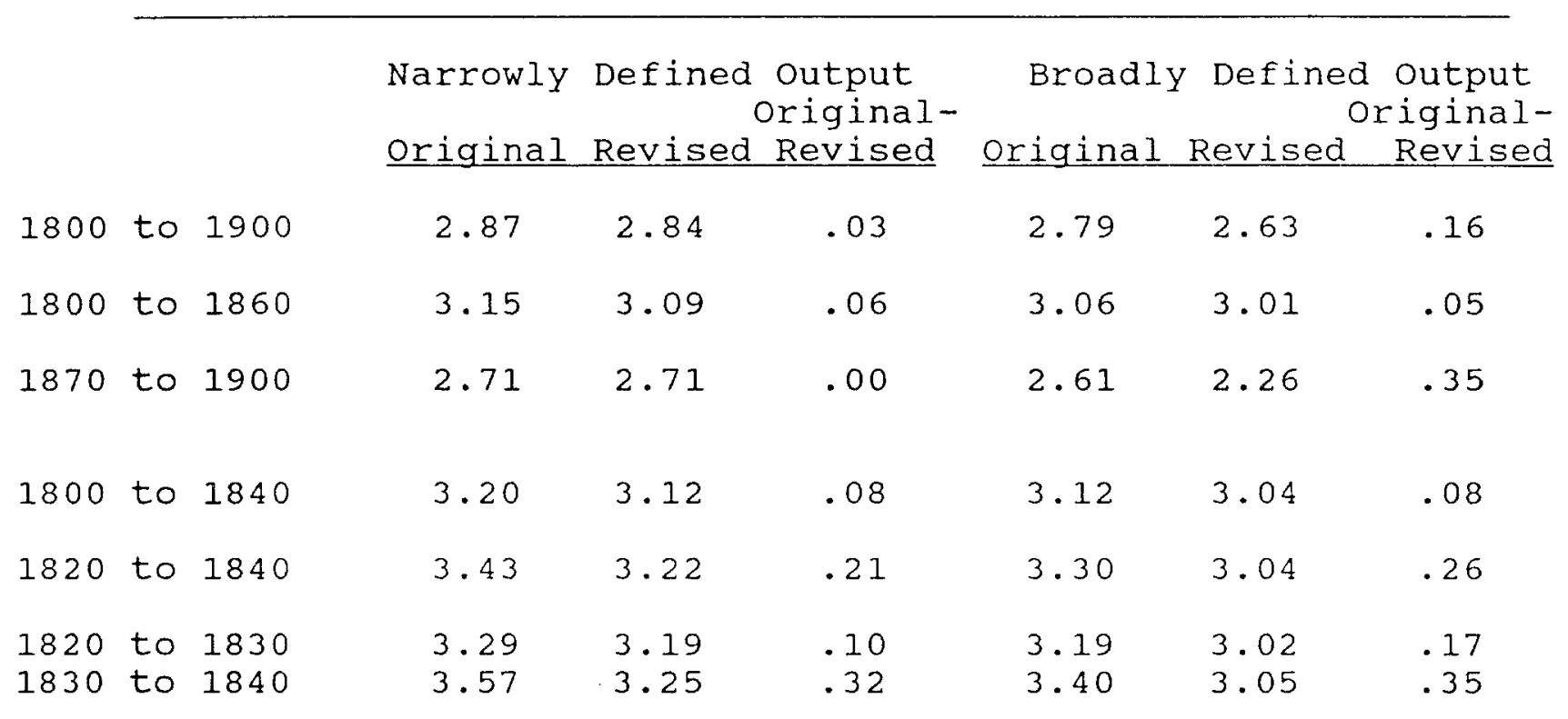

Sources: Towne and Rasmussen, 'Farm Gross Product,' Table 1; and Weiss, 'Revised Estimates.'

Notes: The output in all series is valued in prices of 1840 . The narrowly defined output excludes the value of farm improvements and home manufacturing, the broad definition includes those items. 
differences between the narrow and broad measures are of greater consequence, especially after the Civil war when the broader measure's growth was nearly one-half percent slower per year. The divergence was negligible in the antebellum period, but over the entire century the difference between 2.84 and 2.63 percent growth per year is more noticeable than shown in the original series. This slower growth of the broad measure reflects the decreases in the value of home manufacturing output after 1870.30

\section{III}

The farm labor force figures have been revised more noticeably, and the adjustments are not all in the same direction. 31 The new figures are higher than the previous ones in 1840, 1850, and 1860, by a fairly uniform percentage; 7 percent in 1840, 9 in 1850, and 5 in 1860. In contrast, the new figures for 1800 through 1820 and for 1870 through 1900 are below Lebergott's figures; by approximately 10 to 15 percent in the earlier years, and 5 to 10 percent after the civil war. In spite of these disparities, the two series show almost identical rates of change over the century (2.1 percent per year). The two series reveal noticeable differences over the major subperiods. The Lebergott farm labor force grew more slowly than mine between 1800 and 1860 (2.43 versus 2.70 percent per year) but faster between 1860 and 1900 (1.70 versus 1.54 ).

Disparities between our postbellum figures are due entirely to a difference in our estimates of the numbers of 'laborers, not otherwise specified' who worked in agriculture. 32 There are three reasons for the discrepancies in the antebellum years. 33 
In each year the new estimates incorporate a smaller number of slaves in farming, roughly 75 percent of the rural slave population of working age as opposed to Lebergott's estimate of nearly 90 percent. 34 In 1850 and 1860 this downward bias is more than offset by the addition to farming of workers who had reported their occupation as 'laborer, not otherwise specified.'35 In 1820 and 1840 the new estimates differ from the older ones because of varying judgments about how to correct the census deficiencies. 36

My series seems preferred because its behavior is far more consistent with the changes in the rural population that were taking place. Gallman has argued that 'one would expect to find that changes in the distribution of the labor force between agricultural and non-agricultural activities would roughly parallel changes in the distribution of the population between rural and urban places.' 37 He noted that the Lebergott series showed changes in the farm labor force that seemed inconsistent with the changes in the rural population, especially so in the antebellum period. From 1870 on, the changes in shares were much closer, confirming the relationship postulated by Gallman. My estimates reveal the expected pattern. In virtually every subperiod the changes in the new series accord much better with the changes in the rural population figures. Only over the years 1840 to 1860 does the old series conform more closely, and that mildly superior performance for the twenty year period is the average of two aberrant, but offsetting decadal shifts. The most striking differences in the behavior of the two labor force 
series show up in the 1820 to 1840 period, during which time the rural share of the population declined by 3.6 percentage points. The Lebergott estimates show a very large decline in the farm share of 15.5 percentage points, while my figures reveal a decline of only 4.4 percentage points. Overall, the new series shows a much higher correlation between the change in the farm share and that in the rural population on a decade to decade basis. The correlation coefficient is .91 using the new series but only .24 with the Lebergott figures.

The effects of the revisions to the output and labor force data on the productivity measures are reported in Tables $4 \AA$ and 4B. The separate effects of each adjustment are shown in columns 4 and 5. The sum of those two columns shows their combined effect. The relative importance of the labor force adjustments (shown in col. 6) varies according to whether output is measured narrowly or broadly.

In the narrow version the changes to the output series affect only the first four decades, while labor force adjustments were made in each decade. Where changes were made to both the effects of the labor force revisions predominate, except in the 1830s. Moreover, while the output adjustments raise per worker productivity by small amounts in each of the first four decades, the labor force corrections have a differential impact over the century, raising productivity in the first three decades and the last four, but lowering it in the middle four. 38

In the broadly defined output series the effect of the labor 
Table $4 \mathrm{~A}$ Comparison of Farm Output per worker Figures (Narrow Definition of output in 1840 Prices)

\begin{tabular}{|c|c|c|c|c|c|c|}
\hline & $\begin{array}{c}\text { Original output } \\
\text { divided by } \\
\text { Lebergott's } \\
\text { Labor } \\
\text { Force }\end{array}$ & $\begin{array}{l}\text { Revised ou } \\
\text { divided } \\
\text { Lebergott's } \\
\text { Labor } \\
\text { Force }\end{array}$ & $\begin{array}{l}\text { tput } \\
\text { by } \\
\text { Weiss's } \\
\text { Labor } \\
\text { Force }\end{array}$ & $\begin{array}{r}\text { Chano } \\
\text { due } \\
\text { Revisic } \\
\text { Output }\end{array}$ & $\begin{array}{l}\text { ye } \\
\text { to of } \\
\text { Labor } \\
\text { Force }\end{array}$ & $\begin{array}{l}\text { Labor } \\
\text { Force } \\
\text { Revision's } \\
\text { Share of } \\
\text { Change }\end{array}$ \\
\hline 1800 & $\$ 145$ & $\$ 150$ & $\$ 165$ & $\$$ & $\$ 15$ & $75 \%$ \\
\hline 1810 & 141 & 147 & 169 & 6 & 22 & 79 \\
\hline 1820 & 147 & 153 & 170 & 6 & 17 & 74 \\
\hline 1830 & 171 & 177 & 176 & 6 & -1 & 14 \\
\hline 1840 & 199 & 199 & 186 & & -14 & 100 \\
\hline 1850 & 201 & 201 & 186 & & -15 & 100 \\
\hline 1860 & 220 & 220 & 208 & & -12 & 100 \\
\hline 1870 & 229 & 229 & 244 & & 15 & 100 \\
\hline 1880 & 261 & 261 & 281 & & 20 & 100 \\
\hline 1890 & 287 & 287 & 303 & & 16 & 100 \\
\hline 1900 & 297 & 297 & 331 & & 34 & 100 \\
\hline
\end{tabular}

Average Annualized Rates of Change

Twenty Year Periods

\begin{tabular}{|c|c|c|c|c|c|c|c|}
\hline 1800 & -1820 & .05 & .10 & .14 & .05 & .04 & 44 \\
\hline 1820 & -1840 & 1.54 & 1.33 & .44 & -.21 & -.89 & 81 \\
\hline 1840 & -1860 & .51 & .50 & .57 & -.01 & .07 & 88 \\
\hline 1860 & -1880 & .86 & .86 & 1.51 & - & .65 & 100 \\
\hline 1880 & -1900 & .64 & .64 & .82 & -- & .18 & 100 \\
\hline \multicolumn{8}{|c|}{ Longer Term Comparisons } \\
\hline 1800 & -1840 & .79 & .72 & .29 & -.07 & -.43 & 86 \\
\hline 1840 & -1900 & .67 & .67 & .97 & - & .30 & 100 \\
\hline 1800 & -1850 & .66 & .60 & .24 & -.06 & -.36 & 86 \\
\hline 1850 & -1900 & .78 & .78 & 1.15 & -- & .37 & 100 \\
\hline 1800 & -1860 & .70 & .65 & .38 & -.05 & -.27 & 84 \\
\hline 1860 & -1900 & .75 & .75 & 1.17 & -- & .42 & 100 \\
\hline 1800 & -1900 & .72 & .69 & .70 & -.03 & .01 & 25 \\
\hline
\end{tabular}


Table 4 B

Comparison of Farm Output per worker Figures

(Broad Definition of output in 1840 Prices)

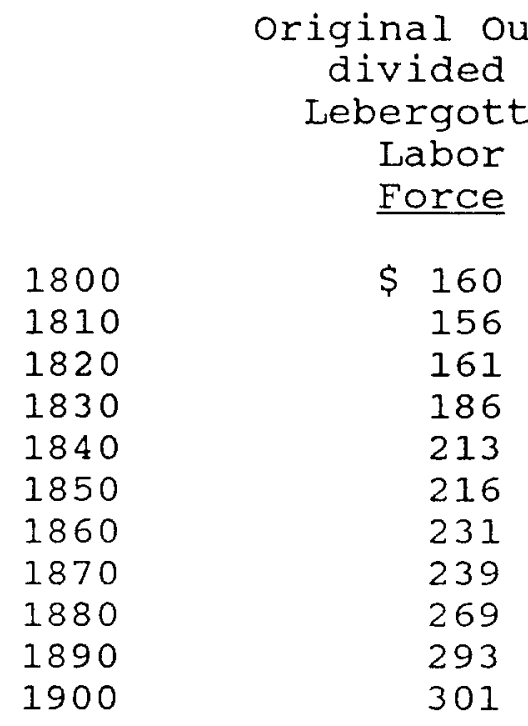

Revised output divided by

Change due to

Lebergott's Weiss's Labor Labor

Force

$\begin{array}{ll}\$ 186 & \$ 206 \\ 184 & 212 \\ 191 & 212 \\ 217 & 216 \\ 240 & 224 \\ 246 & 228 \\ 261 & 246 \\ 265 & 282 \\ 275 & 295 \\ 298 & 314 \\ 301 & 335\end{array}$

Revision of Labor output Force

\begin{tabular}{|c|c|c|}
\hline$\$ 26$ & $\$$ & 20 \\
\hline 28 & & 28 \\
\hline 30 & & $2]$ \\
\hline 31 & - & 1 \\
\hline 27 & - & 16 \\
\hline 30 & - & 18 \\
\hline 30 & - & 15 \\
\hline 26 & & 17 \\
\hline 6 & & 20 \\
\hline 5 & & 16 \\
\hline- & & 34 \\
\hline
\end{tabular}

Labor Force Revision's Share of change

$43 \%$
50
41
3
37
38
33
40
77
76
100

Average Annualized Rates of Change

Twenty Year Periods

$\begin{array}{rr}1800-1820 & .02 \\ 1820-1840 & 1.41 \\ 1840-1860 & .42 \\ 1860-1880 & .77 \\ 1880-1900 & .56\end{array}$

.12
1.15
.41
.26
.46

.16

.10

.26

$-.26$

.04

$29 \%$

77

.48

$-.01$

$-.89$

88

.91

$-.51$

.07

.65

56

.63

$-.10$

.17

63

Longer Term Comparisons

$\begin{array}{rrrrrrr}1800-1840 & .71 & .64 & .21 & -.07 & -.43 & 86 \% \\ 1840-1900 & .58 & .38 & .67 & -.20 & .29 & 59 \\ 1800-1850 & .60 & .56 & .20 & -.04 & -.36 & 90 \\ 1850-1900 & .66 & .40 & .78 & -.26 & .38 & 59 \\ 1800-1860 & .61 & .56 & .30 & -.05 & -.26 & 84 \\ 1860-1900 & .66 & .36 & .77 & -.30 & .41 & 58 \\ 1800-1900 & .63 & .48 & .49 & -.15 & .01 & 06\end{array}$


Notes: The narrow definition of output excludes the value of farm improvements and home manufacturing, the broad definition includes them. Both series are in constant prices of 1840 .

The original output figures were taken from Towne and Rasmussen and revalued in 1840 prices. The revised figures are explained in Weiss, 'Revised Estimates,' Table A-1.

The labor force revision's share of the change was calculated as the share of the sum of the absolute changes caused by the two separate adjustments.

Sources: Towne and Rasmussen, 'Farm Gross Product,' Table 1; Lebergott, 'Labor Force,' Table 1; Paul David, 'The Growth,' Appendix Table I; Weiss, 'U.S. Labor Force,' and 'Revised Estimates.' 
force modifications is about the same in an absolute sense as occurred with the narrower series; productivity is raised in most decades, but lowered in the midale four, and by roughly the same amounts. The effect of the output revision, however, is much greater in the broad series, raising productivity by substantial amounts at the first seven benchmarks, by much smaller amounts at the next two, and not at all in 1900 .

With the narrowly defined output series, the century long rate of productivity growth was about the same regardless of which output or labor force series is used; .72 or .69 with the Lebergott labor series, .73 and .70 with the weiss data. In the two major subperiods, revisions to the output figures have little influence, the antebellum rate being slower by only .05 percentage points per year, and the postbellum rate being unchanged. The rate of growth in each of those periods, however, depends very much on which labor force series is used; the antebellum rate being noticeably slower with the weiss labor force series, the postbellum rate being much faster. 39

Using the broader measure, the large revisions to the antebellum output figures had little effect on the rate of productivity growth before 1860 , but taken in conjunction with the much smaller adjustments after the war, the rate of growth for the entire century was reduced by .15 percent per year. The post-1860 rate was slowed by .30 percent per year. The impact of the labor force revisions were negligible over the entire century, but this reflects offsetting influences within that time span. In the antebellum period, the adjustments to the labor 
force had a noticeable negative effect on productivity growth, especially before 1840. From 1870 on, however, the labor force revisions raised the rate of productivity advance, more than offsetting the negative consequences of the output adjustments. 40

Let me turn now to more substantive issues regarding the growth of farm productivity. As the preceding section made clear, the interpretation depends on which output and labor force series is used. I shall focus here on the behavior of farm productivity that reflects the revised output series (both the narrow and broad measures) and my labor force figures; the first because the revisions (at least in the narrow version) represent only minor corrections to the Towne and Rasmussen figures, the latter because they seem more consistent with the behavior of the rural population movements.

The revised series are presented by component in Table 5 , and the rates of change of total output per worker are shown in Table 6 . That table shows the annual rate of change between any two benchmark dates during the century. For example, using the narrowly defined output (Panel A), the annual rate of change between 1800 and 1810 was .23 percent per year, while between 1800 and 1840 it was .29 percent. These figures, of course, do not show productivity or its rate of change for any specific item because we do not know how the farm labor force was distributed across the various tasks. The figures show only which components were influencing the behavior of the aggregate output per worker statistic. 


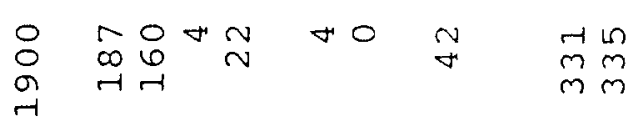

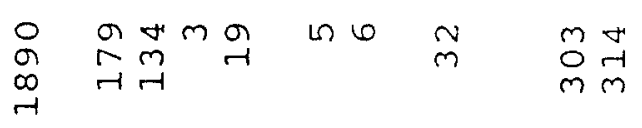

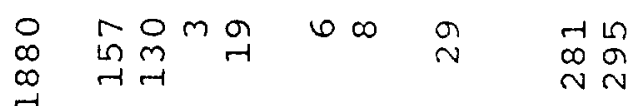

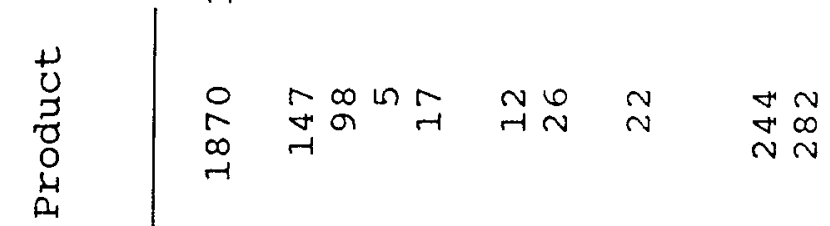



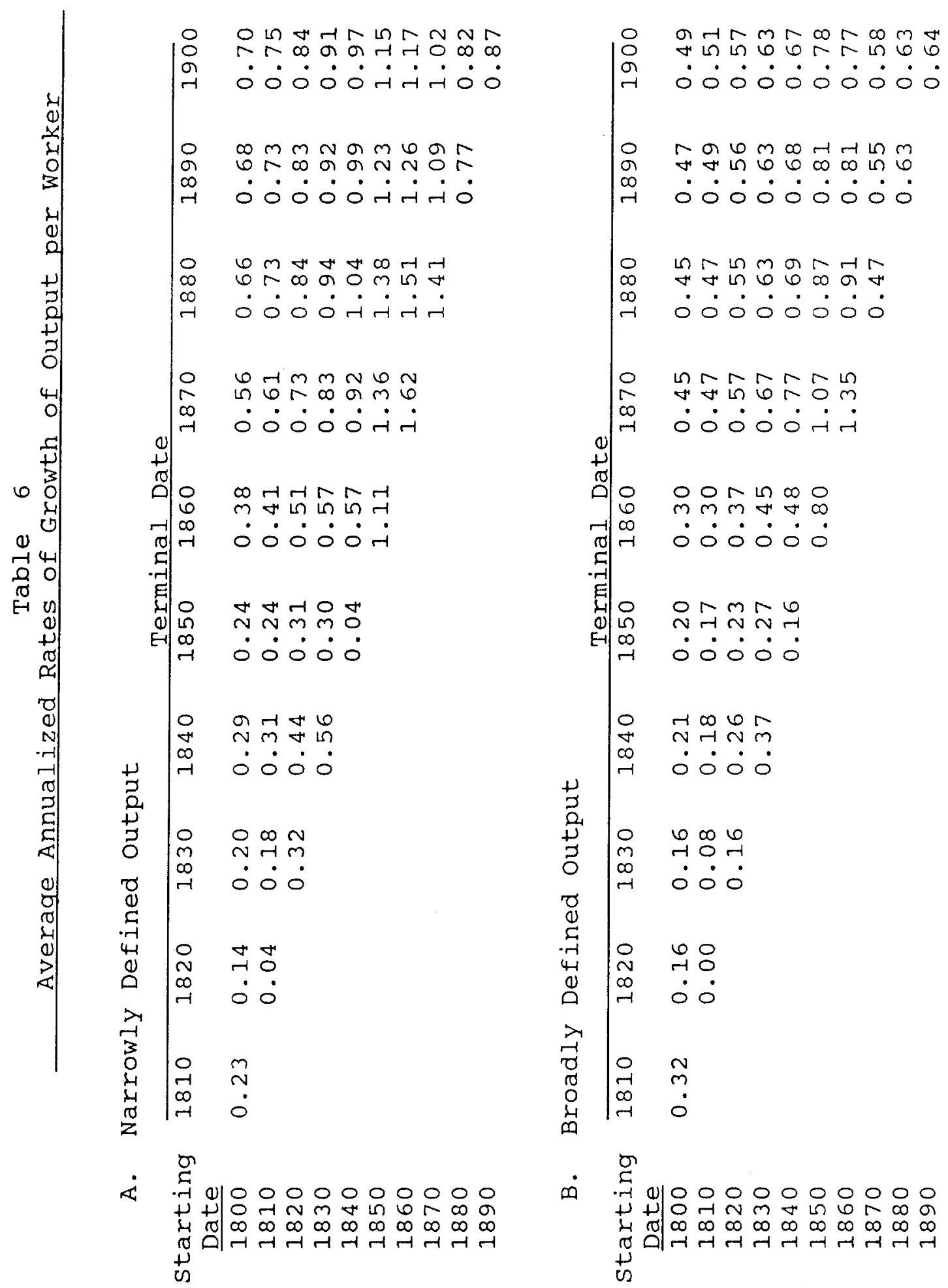
over the course of the nineteenth century the sector exhibited continual advances in output per worker but at a relatively slow pace. The faster growing narrowly defined output showed a modest rate of productivity change of .7 percent per year, while the more broadly defined measure produced growth of only .49 percent per year. As noted above, (Table 4) the rates of productivity change for this long time period are much the same regardless of the underlying labor force series, and in the narrow measure the pace is not much influenced by the corrections made to the output series. Only with the broad measure of output is the result affected by the corrections; the rate of productivity growth being only three-fourths what it was with the original Towne-Rasmussen figures. Whichever series is used, then, the picture is one of rather modest annual growth in output per worker over the course of the entire century.

over the century output per worker, as narrowly defined, showed a net increase of $\$ 165$. The intermediate goods used up in the process of production rose by $\$ 37$, so gross production went up by just over $\$ 200$. A little over half of the gross increase, and fully two-thirds of the net increase, was accounted for by increases in crop outputs per worker which rose from $\$ 51$ at the opening of the century to $\$ 160$ at the close. The other chief component, livestock production, rose by only $\$ 82$. The broad measure of output did not perform quite as well, showing a net increase of only $\$ 130$. The difference between the two reflects the declines in the per worker values of farm improvements and especially home manufactures. To some extent this was the 
farmer's response to increased commercialization, specializing in the marketable crops they were good at and substituting commercially produced industrial goods for home manufactures. The effects of this transformation, however, must be taken into account in judging the progress of the farm sector's welfare. 41 The narrow output measure exaggerates the income effects of the increased farm output. A more proper gauge of the changes in farm prosperity must take into account that some of the increases in crop and livestock production, and thus in farm income, came at the expense of other farm products. The broader measure of output reveals the net outcome of these trade-offs. There were substantial differences in the sector's performance in the ante- and post-bellum decades, and differences as well in the behavior of the components. The bulk of productivity advance took place in the postbellum period. In the narrow measure approximately three-fourths of the productivity advance occurred after 1860 ; in the broad measure roughly two-thirds occurred during that time.

In the postbellum period the livestock component made a relatively greater contribution to pushing up the aggregate figure. 42 Between 1860 and 1900 livestock output rose relative to the farm labor force by $\$ 73$. This was 90 percent of its century long increase, and slightly larger than the $\$ 70$ postbellum rise in crop output per worker. There were sharp differences in the growth of the various livestock products during this period. The two largest components, cattle and calves and hog production, were responsible for only one-third of 
the increase in livestock output. Cattle and calf output per worker rose by $\$ 18$, all of the increase taking place between 1870 and 1890, while hog production showed a net increase of only $\$ 6$, having risen initially then declining by $\$ 16$ after 1870 . The big source of the increase was dairy production which rose by $\$ 24.43$ The postbellum years bore the full brunt of the decline in home manufacturing and farm improvements. The sum of these two items declined from a value of $\$ 38$ in 1860 to only $\$ 4$ in 1900. As a consequence, there was a substantial difference between the increase in the narrow and broad measures of output per worker over the postbellum period, $\$ 122$ versus only $\$ 88$.

In the antebellum period, the more obvious consequences of the new labor force estimates are to raise the levels of output per worker in farming in the opening decades of the century, and lower them in the late ones. Nonetheless, the growth of output per worker in the new series is similar to that in the old in two of the three twenty year subperiods, 1800 to 1820 and 1840 to 1860. In the latter period the levels of output per worker are different, by approximately 7 percent, but their growth is nearly identical (.50 versus .57 percent per year). Likewise, the results are very similar for the earliest 20 year period. Again the levels of farm output per worker differ, by about 10 percent, but the rates of growth of productivity are equally low (.10 versus . 14).

In the middle 20 years, however, there are substantial differences between the two series. In this critical period, the new series shows much slower growth of output per worker (.44 
versus 1.33 percent per year), stemming predominantly from the faster growth of the farm labor force evident in the new series. As a consequence, over longer time spans that encompass this subperiod, the fully revised series produces a much slower rate of productivity growth than does the original; for example, .65 versus .38 percent average annual increases between 1800 and 1860. The new series again supports the traditional view that it was only after 1840 that American agriculture benefitted from the experimentation and technological developments that may have been discovered before that time.

The focus of this article is on the long term changes in productivity, but the remarkable short term performance over the Civil war decade cannot be ignored. That decade did not merely mark a point of transition to a more mechanized, productive agriculture, it led the way. Output per worker increased at the fastest rate of the century during the war decade.44 A full explanation of this increase in output per worker is too detailed to be covered here, but a few comments seem necessary.

The remarkable feature of this advance is that it occurred with, by far, the slowest growth in output of any decade. Farm gross product increased by only 1.74 percent per year over the 1860s, while in virtually every other decade the increase exceeded 2 percent per year, and was often above 3 percent. 45 For the century the rates of growth of output were 2.84 percent per year in the narrow measure, 2.63 in the broad. The sharp advance in productivity, then, reflects a much slower growth in the farm labor force than in output. 46 
While output grew faster than the labor force overall, this varied greatly by product. In fact, only a handful of products increased faster than the labor force, but their rise was enough to propel the aggregate figure upward sharply. The products responsible were wheat, which increased by $\$ 7$, and several livestock products - chickens, eggs, dairy products, and especially hogs. Mind you, the expansion in these specific product lines does not necessarily mean that productivity improvements took place there. The increases in these products may reflect largely, perhaps entirely, an increase in the inputs used in their production. Some of the increased effort must have been made possible by productivity improvements in the production of other crops which freed up resources, but some of it probably came at the expense of leisure as farm families responded, grudgingly in some cases, to the increased commercialization of certain products.

The increase in livestock production, in particular, suggests that mechanization induced by the War's labor shortages was not the only force behind the productivity increases. The chief source of the increase in aggregate output per worker and of the sharp rise in the value of livestock output relative to the labor force was hog production. 47 Nearly all of the $\$ 36$ net increase in aggregate output per worker is accounted for by the \$33 rise in livestock production, and hog production alone accounted for $\$ 22$. Since the raising of hogs has not been identified as a locus of much mechanization, some other explanation must account for the productivity increases 
associated with the war decade. 48

Part of the overall increase in output per worker no doubt reflects the fact that women and children took up some of the slack on a temporary basis during the war and remained active after its conclusion, and unfortunately their participation in the labor force is not accurately measured in the census data. This must surely be behind the increase in the per worker output of chicken and eggs, which combined rose by over $\$ 4$ or nearly 50 percent, and dairy products, which rose by $\$ 2$ or about 10 percent, but it is a likely source of increased output of other crops as well.

Lying behind the decade's upsurge was increased commercialization, spurred initially by the conflict. The war seems to have called forth some additional output, especially of livestock products, if only on a temporary basis. 49 The industry produced sharply higher levels of output during the War, averaging $3.2 \mathrm{million}$ hogs per year between 1861 to 1864,38 percent above the average for the preceding four years. The high level of production in 1870 perhaps then reflected a lag in the adjustment to civilian market demand after the war. 50 The expansion and improvement of Chicago's packing facilities with the opening of the Union Stock Yards in December 1865 would have helped sustain the higher levels of output. 51 Increased commercialization is not likely to be the complete explanation for the decade's performance, however, because the full effects of these and other marketing improvements did not materialize until after 1870.52 
As one of the world's most developed countries, the U.S. growth performance has been a source of envy, a record to be emulated. While the overall accomplishment is remarkable, the nation's growth of per capita income has been less noteworthy. 53 Nonetheless, that rate of growth of around 1.6 percent per year from 1800 to 1980, qualified it for inclusion in simon Kuznets's set of countries that experienced modern economic growth; those countries where per capita income had grown at 1.0 percent per year or more for more than 50 years. Had U.S. growth in national income per capita depended only on the performance of the agricultural sector, however, the country would not have qualified. While productivity advance in agricultural was positive, and facilitated other structural changes that contributed to per capita income growth, it was in fact a modest record.

The pattern of advance in the new productivity series supports the traditional view of American agriculture with a vengeance. The civil war, or at least the decade of that conflict, marked a clear turning point in the course of productivity, although it is easy to see that one might date the shift a decade earlier. Productivity growth was moderate but sustained, and accelerated over the course of the century as biological and mechanical experimentation came to fruition. The performance after the civil war was clearly superior to that before 1860. Whether one looks at the broad or narrow measure of output the growth of the later decades exceeded that in the 
opening of the century by a wide margin; nearly twice as fast in the broad and three times so in the narrow measure.

This pattern is different from the surprising implication of the Lebergott labor force series pointed out by Gallman that farm productivity advanced more rapidly in the first half of the century than in the latter half, a pattern that ran 'counter to the burden of the narrative histories of the period.'54 In that old version farm labor productivity increased at about the same rate in the two half centuries and faster in the first four decades than in the rest of the century. With the new labor force figures productivity grew much more rapidly after 1840 than before, .97 percent per year versus .29 in the narrow measure, .67 versus .21 in the broader version. Moreover, the same pattern prevails whether the century is divided at 1840, 1850, or 1860.55 In fact, from 1850 or 1860 to the end of the century the narrowly defined output per worker advanced at the healthy rate of around 1.16 percent per year, the broader measure at .8 percent per year.

It seems clear that the civil War decade's performance merits further study. It may even be that some of the progress observed here is a statistical artifact, especially the favorable achievement in hog production. 56 some of the increase in output per worker was no doubt real, but the sources of the advance would not seem to be the sort that underlay the traditional view of a transition to a period of more rapid productivity growth. Whether this new pattern of advance can be tied in with the more traditional explanations about mechanization and the use of 
family labor remains to be seen.

The changes in productivity and the labor force were part of other well known trends in the broader aspects of farm life, in particular with the demise of the family farm. According to Atack and Bateman '...as of the 1860s a landowning yeomanry, the North's appealing but nevertheless peculiar institution, still seemed possible.' And while 'tiny and incipient cracks .. in the facade' had appeared before the war, it was only afterwards that commercial forces 'would sweep it ultimately in the realm of nostalgia.'57 The eventual demise of the family farm was, of course, influenced by many forces. The impact of some of these, such as unfavorable price movements, waxed and waned. Over the long term, the downward trend must have been mightily influenced by advances in productivity. In this sense the post-war acceleration in productivity evident in the revised series seems more consistent with the demise of yeoman farming. 


\section{Footnotes}

1. This paper has benefited from the comments of Jeremy Atack, Fred Bateman, Lou Cain, Lee Craig, stan Engerman, and John Lyons. The work was financed in part by the National science Foundation (No. SES 8308569). This research is part of the NBER's program in Development of the American Economy. Any opinions expressed are mine and not those of the National Bureau of Economic Research.

2. See Cochrane, The Development; Schlebecker, whereby we Thrive, pp.36-38; and Schmidt, "Agriculture."

3. The price index for crop and livestock output was lower in 1900 than in 1800 'Towne and Rasmussen, 'Farm Gross Product,' Table 1, p.266.

4. Most current textbooks say very little about the course of progress over the century, in particular leaving the precise rate and pattern of advance unspecified.

5. For a more recent view in this vein see Rothenberg 'The Market.'

6. Ross and Tontz, 'The Term,' p.35.

7. $\quad$ ibid., pp. 36-38.

8. Parker does allow the possibility of some acceleration in that before 1830 'the processes of changed moved slowly; and marked and sustained rises in productivity almost certainly did not occur.' Presumably afterwards there was faster, more sustained progress. 'Agriculture,' pp. 370-72.

9. Ross and Tontz, 'The Term,' p.34. 
10. Hurt, 'Northern Agriculture,' p.53.

11. Rasmussen, Readings, p.103. In Schmidt's view 'The Civil War marks the beginning of..the revolution in agriculture.' 'Agriculture,' p.587.

12. Ross, 'The Expansion,' p.389. These views were echoed by Schlebecker, 'Technology and science seemed to dominate American agriculture from 1861 to $1914 . '$ Whereby We Thrive, p.151.

13. Bogart, The Economic History, pp.77-78. He did go on to say that "The application of machinery to agriculture which had begun before the war, was now made on a still more extensive scale.." ibid., p.117.

14. Gray, History of Agriculture, p.254. Taylor, in 'American Economic Growth,' echoed this sentiment that 'although many improvements were being developed during this period, their use did not become sufficiently widespread appreciably to affect production until after 1840 ' $^{\text {ibid., }}$ p.442.

15. Cochrane, The Development, p.69. More recently, Rikoon made the same point about threshing machine adoption, Threshing, p.23.

16. Danhof, Change in Agriculture, pp. 140-41.

17. Cooper, Barton, and Brodell, Progress, p.6. Unfortunately, they did not specify how they calculated their productivity estimates. Parker and Whartenby cast doubt on the cooper, Barton, and Brodell estimates, 'The Growth of output,' p.207. Parker and Klein imply that most productivity growth occurred 
after 1850 'Productivity Growth.'

18. Perhaps the transition occurred earlier in New England Bidwell, 'The Agricultural Revolution.'

19. David, 'The Growth,' pp.151-97. As I have pointed out elsewhere, in this revisionist view the productivity increase between 1820 and 1840 was the most rapid of the century. 'Economic Growth Before 1860.'

20. Gallman 'The Agricultural Sector,' pp. 36-38. See also Gallman 'The statistical Approach,' $p .81$ in which he argued that the problem lay in the farm-nonfarm distribution of the 1800 labor force figures.

21. Lebergott developed the estimation methods and produced the original estimates, while David revised some of the figures, especially those for 1800. Lebergott now accepts David's revision for 1800, so there is very little difference between the two series. While both had a hand in the work, for ease of exposition I call it the Lebergott series.

22. Towne and Rasmussen, 'Farm Gross Product,' Their output measure is the value of farm output entering gross national product. It is calculated as the difference between the total value of output and the value of intermediate products consumed in the process of production.

23. This constancy on a per capita basis was expressed differently for various products; constant output for some, consumption for others, and disappearance for a few. Towne and Rasmussen, 'Farm Gross Product.' 
24. Had these three products shown the assumed constancy in the period 1820 to 1840 then crop and livestock output per capita would have risen by only $\$ 3.12$, or about 8 percent, instead of $\$ 4.72$ or 13 percent. The contrast with the subsequent 20 years would be much reduced.

25. Another small anomaly in the Towne-Rasmussen series is that the value of hog production per capita in 1800 and 1810 is slightly higher than the values for 1820 and 1830. The former are equal to the 1840-50 average while the latter are equal to the average for the three years 1840,1850 , and 1860.

26. As explained in an appendix to this paper, Thorp's annals suggest that 1840 may have been one of the better crop years, although not necessarily better than 1800 or 1860. Gallman ('A Note,' pp.185-95) has described the 1840 harvest as average, and has argued that the 1839-40 livestock figures are higher than comparably defined figures for later years ('Value Added,' pp.113-16)

27. Fogel, 'Nutrition' Fig.1, and Komlos, 'The Height and Weight.' It is possible that heights before 1830 were maintained with lesser diets, while in 1840 and after they declined with the same or better diets because of other drains on nutrition, such as more intense work effort, diarrheal disease, or other consequences of urbanization. 
28. An alternative consideration was to lower the 1840 figure as well, but this was rejected because the direct estimates of farm output and national product for the years 1839 through 1859 accept the 1840 census figures, and there seems little justification for now requiring that we also revise that set of estimates.

29. The revisions to the values of home manufacturing and farm improvements are those made by Gallman for 1839 to 1899 , but revalued in 1840 prices and extended back to 1800 . The methods of extension to 1800 are explained in an appendix to this paper, available from the author.

30. These compositional details are presented in the appendix to this paper, table $A-1$ in particular.

31. In concept and coverage the new farm labor force figures are similar to Lebergott's. MY estimation followed his procedures but was executed at the state and regional level. The estimates are described in somewhat greater detail in the appendix to this paper. A more complete description of the estimating procedures and comparisons with Lebergott's figures are presented in weiss "U.S. Labor Force."

32. See my 'Estimation of the Farm/Nonfarm.'

33. The antebellum estimates are explained in detail in my 'U.S. Labor Force.'

34. See my 'Assessment and Revision: 1820 and 1840.' 
35. Previous estimates had placed all these workers in nonfarm industries, but careful examination of the state data, and the location of many of these workers in rural areas, argues for the assignment of any of them to farming. See my 'Estimation of the Farm/Nonfarm.'

36. For details see my 'U.S. Labor Force.' The corrections and additions to the census counts of farm workers amounted to 233,000 in 1820 and 164,000 in $1840 ;$ increases of 11.3 percent and 4.5 percent respectively.

37. Gallman, 'The Agricultural sector,' p.38.

38. My allocation of a smaller number of slaves to agriculture raised the level of worker productivity in each antebellum year, by 8 to 13 percent using the narrow measure and 11 to 16 percent using the broadly defined series. The rates of productivity growth, however, were not changed much at all, being lowered by only .004 percent between 1800 and 1860 and by only .05 percent per year over the entire century.

39. Over shorter time periods, the alterations in the output figures have a noticeable effect only in the 1820 s and 1830 s. Regardless of which labor force series is used, productivity growth is slower over that 20 year period by .2 percent per year. 40. There are more noticeable effects in specific decades. The output adjustments slow the growth noticeably in the 1820 s and 1830 s and between 1860 and 1880 . The labor force revisions have a substantial effect in those same decades, but the direction of the impact varies. In the 1820 to 1840 period the labor force 
adjustment amplifies the negative impact of the output changes, while in the postbellum period it offsets the output effect.

41. It is possible that farmers substituted leisure for the hours devoted to home manufacturing and improvements, but Kendrick's data suggest otherwise. The average workweek in farming remained constant from 1869 through 1909 (Productivity Trends, $\mathrm{p} .310$, Table A-IX).

42. Winters 'The Economics,' pp.82ff, provides a recent explanation of the shift from wheat to feed-grain and Iivestock farming in response to improved rail and marketing facilities.

43. See Bateman, 'Improvement,' and 'Labor Inputs,' for an explanation of the rise in dairy output after 1850 .

44. This national performance masks substantial regional differences as the labor forces and output grew at much different rates in the various regions and subregions. Preliminary calculations indicate that output per worker declined by 1.7 percent per year in the South, while it rose by 3.2 percent per year elsewhere.

45. The slow growth of cotton output over the civil war decade (.08 percent per year) dragged down the annual rate of growth of farm gross product by about .25 percent per year.

46. On the face of it, this accords well with the view that by having drawn off much of the farm labor, the civil war spurred mechanization, in particular the adoption of the reaper. 
47. Over the civil war decade hog output rose from 6,200 to 9,290 million pounds, or from 197 pounds per capita to 232 pounds (Towne and Rasmussen, 'Farm Gross Product,' p.284).

48. As already mentioned, mechanization could have increased livestock output indirectly if the labor saved in the raising of wheat and other crops were shifted to the production of other products.

49. See Clemen, American Livestock, p.85-87, and Walsh, Midwestern Meat Packing, pp.8-59.

50. One example of such a lag is that Armour made the vast majority of his fortune by signing a contract with the Union army to supply it with wartime quantities at wartime prices for three years starting in late 1864. (I am grateful to Lou Cain for this insight).

51. See Clemen, American Livestock, pp. 86 and 108.

52. See Clemen, The American Livestock, pp.108-109; Walsh, Midwestern Meat Packing, p.85; and Yeager, competition and Regulation. While these packing and marketing developments may not explain fully the civil war decade's progress, they contributed to the continued rise in beef production. After 1870 hog output per worker declined, but cattle output increased.

53. The high current level of U.S. per capita income reflects the length of its growth period, its high initial level of income, and its modest rate of growth of per capita income (See Kuznets, The Economic Growth). 
54. Gallman, 'The Agricultural Sector,' p.36.

55. With Lebergott's labor force, the date at which the century was divided had some bearing on the picture. If the break were placed at 1850 the rates are .66 in the first half, .78 in the second; if broken at 1860 the rate for the earlier period was .7, for the latter .75 percent per year.

56. That series is a combination of two different output series. The Towne and Rasmussen series linked the Strauss and Bean figures for 1870 to 1900 with Gallman's estimates for 1840 to 1860. The figures were intended to be conceptually alike, obtained by applying the same slaughter rate in each year to the January 1 inventories, and then converting to a live weight basis using similar average slaughter weights (Towne and Rasmussen, 'Farm Gross Product,' p.284). In an editor's note to that discussion, william Parker argued that the estimates of hog output were too high before 1900, but did not indicate whether the bias was greater before 1870 (ibid., p.284).

57. Atack and Bateman, 'Yeoman Farming,' p.48. 


\section{References}

Atack, J. and Bateman, F., To Their Own Soil (Ames, 1986).

Atack, J. and Bateman, F., 'Yeoman Farming: Antebellum America's other "Peculiar Institution," in L. Ferleger, ed. Agriculture and National Development (Ames, 1990), pp. 25-52.

Bateman, F. 'Improvement in American Dairy Farming, 1850-1910,' J. Econ. Hist., XXVIII (1968), pp. 255-73.

Bateman, F. 'Labor Inputs and Productivity in American Dairy Agriculture, 1850-1910,' J.Econ. Hist., XXIX (1969), pp. 206-29.

Bateman, F. and Foust, J. 'Agricultural and Demographic Records of 21,118 Rural Households,' Data Tape, Indiana University, (1973).

Bidwell, P. "The Agricultural Revolution in New England," Amer. Hist. Rev., 26 (1921), pp. 683-702.

Bidwell, P. and Falconer, J., History of Agriculture in the Northern United States, 1620-1860 (Washington, 1925).

Bogart, E., The Economic History of American Agriculture (New York, 1923).

Clemen, R., The American Livestock and Meat Inciustry (New York, $1923)$.

Cochrane, W., The Development of American Agriculture

Minneapolis, 1979).

Cooper, M., Barton, G. and Brodell, A., Progress of Farm

Mechanization U.S. Department of Agriculture, Misc. Publication No.630 (Washington, D.C., 1947).

Danhof, C., 'Agriculture' in Harold Williamson (ed.) Growth of the American Economy, 2nd ed. Englewood Cliffs, 1951).

Danhof, C., Change in Agriculture (Cambridge, 1969).

David, P., 'The Growth of Real Product in the United states Before 1840: New Evidence, Controlled Conjectures,' I. Econ. Hist., 27 (1967), pp. 151-197.

Fogel, R., 'Nutrition and the Decline in Mortality since 1700: Some Preliminary Findings,' in S. Engerman and R. Gallman, eds. Long-Term Factors in American Economic Growth (Chicago, 1986).

Gallman, R. 'Value Added by Agriculture, Mining, and Manufacturing in the United States, 1840 to 1880,' (unpublished Ph.D thesis, University of Pennsylvania, 1956). 
Gallman, R. 'A Note on the Patent office Crop Estimates, 1841$48, '$ J. Econ. Hist., 23 (1963).

Gallman, R., 'Gross National Product in the United States, 18341909,' in D. Brady ed. output, Employment, and Productivity (New York, 1966).

Gallman, R., 'The Statistical Approach: Fundamental concepts Applied to History,' in G.R.Taylor and L.F.Ellsworth, eds.

Approaches to American Economic History (Charlottesville, 1971).

Gallman, R., 'Changes in Total U.S. Agricultural Factor Productivity in the Nineteenth Century," in D. Kelsey, ed. Farming in the New Nation (Washington, D.C., 1972).

Gallman, R., 'The Agricultural sector and the Pace of Economic Growth: U.S. Experience in the Nineteenth Century,' in D. Klingaman and $\mathrm{R}$. Vedder, eds., Essays in Nineteenth century Economic History (Athens, OH., 1975).

Gray, L.C., History of Agriculture in the Southern United states to 1860 (Washington, D.C., 1933).

Hurt, R.D., 'Northern Agriculture after the Civil War, 18651900,' in L. Ferleger, ed. Agriculture and National Development (Ames, 1990), pp. 53-74.

Kendrick, J., Productivity Trends in the United states (Princeton, 1961).

Komlos, J., 'The Height and Weight of west Point cadets: Dietary Change in Antebellum America,' J. Econ. Hist., 47 (1987), pp. 897-927.

Kuznets, S., 'Current National Income Estimates for the Period Prior to 1870,' Review of Income and Wealth, 2 (1952).

Kuznets, S., The Economic Growth of Nations (Cambridge, 1985).

Lebergott, S., 'Labor Force and Employment, 1800-1960,' in D. Brady, ed. output, Employment, and Productivity (New York, 1966).

Parker, W., 'Agriculture,' in Lance Davis, et. al., eds. American Economic Growth (New York, 1972).

Parker, W. and Klein, J., 'Productivity Growth in Grain Production in the United States, 1840-60 and 1900-10,' in D. Brady, ed., output, Employment, and Productivity (New York, 1966).

Parker, W. and Whartenby, F., 'The Growth of output Before 1840,' in $W$. Parker, ed., Trends in the American Economy in the Nineteenth Century (Princeton, 1960). 
Rasmussen, $W .$, Readings in the History of American Agriculture (Urbana, 1960).

Rasmussen, W., 'The Civil War: A Catalyst of Agricultural Revolution," Agric. Hist., 39 (1965), pp. 187-95.

Rinkoon, J., Threshing in the Midwest, 1820-1940 (Bloomington, 1988).

Rogin, I., The Introduction of Farm Machinery, University of California Publications in Economics, 9 (1931).

Ross, E., 'The Expansion of Agriculture,' in H. Williamson, The Growth of the American Economy (New York, 1946).

Ross, E. and Tontz, R., "The Term "Agricultural Revolution" as Used by Economic Historians,' Agric. Hist. 22 (1948)

Rothenberg, W., 'The Market and Massachusetts Farmers, 17501855,' J. Econ. Hist., 41 (1981), pp. 283-314.

Schlebecker, J., Whereby We Thrive: A History of American Farming, 1607-1972 (Ames, 1975).

Schmidt, L., 'Agriculture in the United states,' The Encyclopedia of the Social Sciences (1930).

Towne, M. and Rasmussen, W., 'Farm Gross Product and Gross Investment in the Nineteenth Century,' in W. Parker, ed. , Trends in the American Economy in the Nineteenth Century (Princeton, 1960).

Walsh, M., The Rise of the Midwestern Meat Packing Industry (Lexington, 1982).

Weiss, T., 'Assessment and Revision of the Antebellum Census Labor Force statistics: Part I, 1850 and 1860 ; Part II, 1820 and 1840,' (unpublished paper, University of Kansas, 1989)

Weiss, T., 'Estimation of the Farm/Nonfarm Distribution of Laborers, not otherwise specified; by state, 1850 to 1900" (unpublished paper, University of Kansas, 1987).

Weiss, T., 'U.S. Labor Force Estimates and Economic Growth, 1800 to 1860,' in R. Gallman and J. Wallis, eds., The standard of Living Before 1860 (Chicago, 1991).

Winters, D., 'The Economics of Midwestern Agriculture, 18651900,' in L. Ferleger, ed. Agriculture and National Development (Ames, 1990), pp. 75-96.

Yeager, M., Competition and Regulation (Greenwich, 1981). 